\section{Joel Mokhoathi}

Dr. Joel Mokhoathi, Faculty

of Theology and Religion,

University of the Free State,

Bloemfontein. E-mail:

Mokhoathij@ufs.ac.za

\section{Lodewyk Sutton}

Prof. Lodewyk Sutton, Faculty

of Theology and Religion,

University of the Free State,

Bloemfontein.

E-mail: Suttonl@ufs.ac.za

DOI: http://dx.doi.

org/10.18820/23099089/actat. Sup32.1

ISSN: 1015-8758 (Print) ISSN: 2309-9089 (Online)

Acta Theologica 2021

Supp 32:i-xii

Date received:

5 November 2021

Date published:

10 December 2021

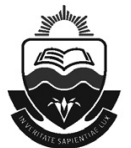

Published by the UFS http://journals.ufs.ac.za/index.php/at (c) Creative Commons With Attribution (CC-BY) ACCESS

\section{Preface and Interviews}

During 2020-2021 the Faculty of Theology and Religion at the University of the Free State celebrated its 40 years of existence, using the theme "Transforming theology and religion?". The celebrations started early in the year 2020 with the academic conference $A$ battle for the heart. How (not) to transform church and society, hosted by the Department of Practical and Missional Theology. A number of local and international scholars attended this conference.

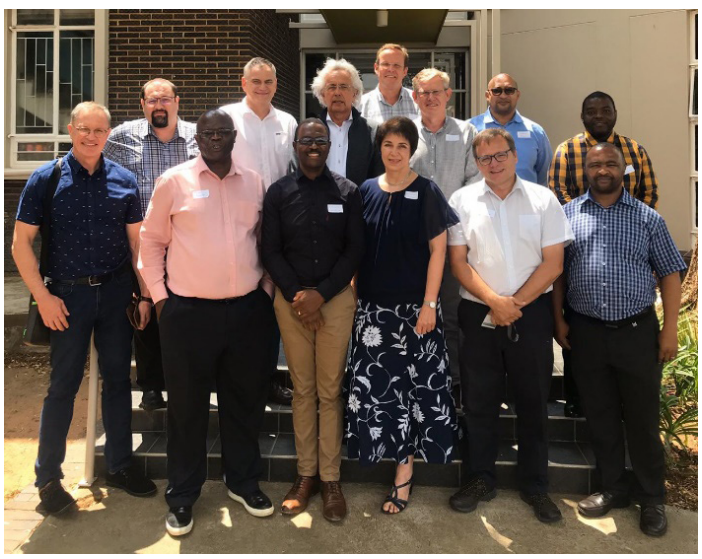

Speakers at the conference "A battle for the heart. How (not) to transform church and society"

In March of the same year, a public lecture was hosted by the Department Old and New Testament Studies. The speaker for this lecture was Prof. Stefan Fischer from the University of Vienna, with a paper titled The transformation of theology and religion in and by the Biblical wisdom literature. Unfortunately, the COVID-19 pandemic and resulting restrictions caused the rest of the planned programme to be postponed. 


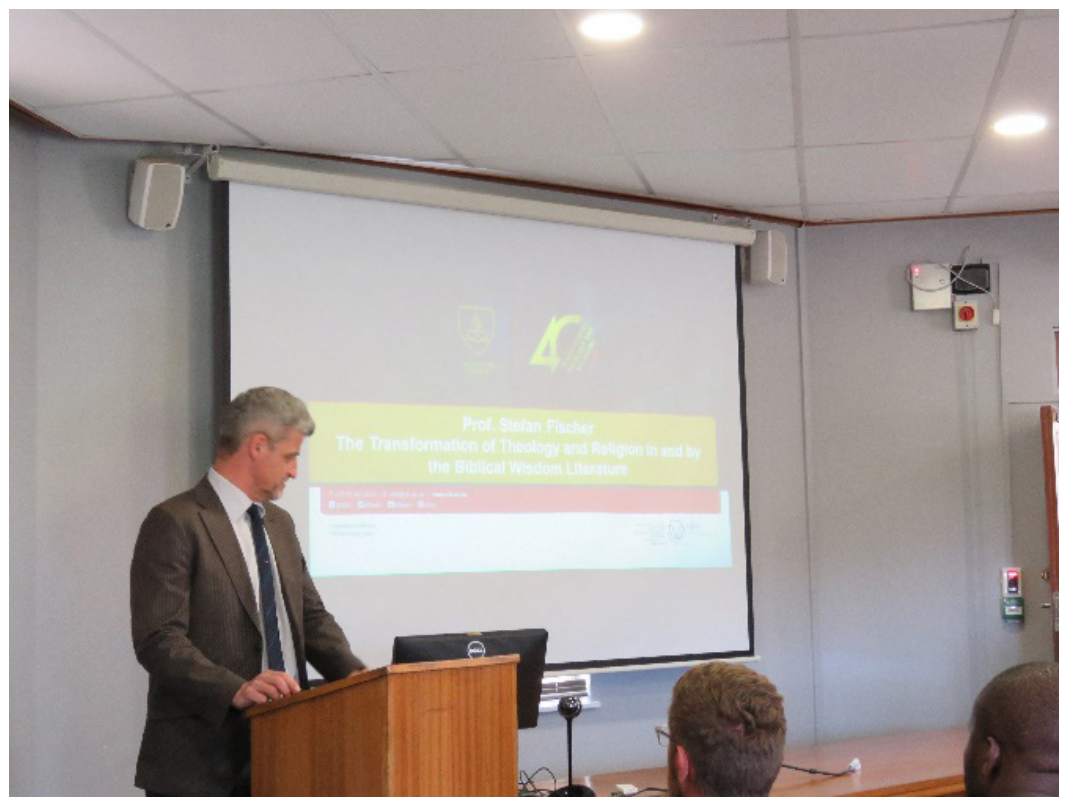

Stefan Fischer, public lecture

Part of the celebration is this publication, which is dedicated to the Faculty of Theology and Religion and all of her staff through the first 40 years. As part of the celebration, we asked Prof. Francois Tolmie, a former student, dean and current professor in the Faculty, to provide us with a reflection of his own experiences in the Faculty over the past 40 years, whereafter we asked the current Dean, Prof. Rantoa Letšosa a few question on how he perceives the future of the Faculty.

\section{INTERVIEW WITH PROF. FRANCOIS TOLMIE}

Prof. Tolmie, as a former student and the institutional memory of this Faculty, what are your sentiments on the profound history and heritage of the Faculty? Having been a dean of the Faculty, what do you feel are some of the milestones that have been achieved in terms of transformation over the past 40 years?

I first set foot on the campus of the University of the Orange Free State (as it was known then) and, in fact, in Bloemfontein, in January 1978, in a South Africa almost unimaginably different from what it is nowadays. The University was one of several White Afrikaans-speaking universities 
in the country and only had roughly 9000 students. My plan was to study at this University for three years, first for an undergraduate degree (called the BA "Admission"), which was necessary to gain entrance to theological studies, which was offered as a postgraduate programme only in those days. Since this University did not have a Faculty of Theology, I planned to do the first three years in Bloemfontein before moving to the University of Stellenbosch to complete the final four years of the seven-year theological training that one needed to become a minister in the Dutch Reformed Church.

However, things worked out differently: During my undergraduate years at this University, the University management and the Dutch Reformed Church jointly decided to offer theological training, specifically meant for the training of ministers of the Dutch Reformed Church. The first intake of students for the new Faculty was in 1981 (with Prof. Mias de Klerk appointed as the first dean). I started my theological studies at this Faculty in 1982. After the completion of my studies and a brief time in the ministry in Walvis Bay, I was appointed as lecturer in New Testament in April 1990.

Over the years, I have watched the Faculty being transformed stepby-step. It started out as an institution meant only for students planning to become ministers of the Dutch Reformed Church, but things slowly changed. In the 1990s, students studying for other White denominations were also admitted. In the next phase, students from the (Black) sister churches of the DRC were allowed to enrol, which meant that Black students were accepted as students and English was introduced as the second language of instruction. During this time, the first Black lecturer, Dr David Keta, was appointed in the Department of Biblical Studies.

During the deanship of Prof. Pieter Potgieter, the relationship between the Faculty and the DRC was redefined and the Faculty started thinking of itself as an ecumenical faculty. This notion slowly came to fruition during the terms of the next three deans (Van Zyl, Tolmie and Snyman). During the term of Prof. Jonathan Jansen's rectorship, the Faculty became the first theological faculty in South Africa to embark on a thorough academic investigation of the notion of epistemological transformation and its practical implications for each theological discipline and the Faculty as a whole. The outcomes were published in a book titled Transforming Theological Knowledge - Essays on Theology and the University after Apartheid (editors: Rian Venter and Francois Tolmie, 2012). The insights gained during this process would influence strategic thinking at the Faculty for many years to come. 
In 2016, the Faculty's name was changed to "Faculty of Theology and Religion" and the seven departments were reorganised to form four departments. In 2019, Prof. Rantoa Letšosa became the first Black dean of the Faculty. Over the past three years, student numbers of the Faculty have increased dramatically, so that the student body now truly reflects the South African situation.

To have been part of this very interesting - and sometimes unexpected journey has been a wonderful privilege. What strikes me most with regard to the process of transformation that unfolded over the years is that it reflected two important aspects. First, the notion of vocation: the transformation embodied a firm conviction by all of us who were involved in the process, that we are called to practise theology in the South African society in such a way that we can enrich the lives of all South Africans. Secondly, the process of transformation reflected the wonderful richness of the theological traditions of which we are privileged to be part, and, in particular, of the richness of our source text, the Bible, from which novel insights and fresh and inspiring ideas may always be drawn.

\section{INTERVIEW WITH PROF. RANTOA LETŠOSA}

Prof. Letšosa, as the current Dean of the Faculty, in your view, what is the significance of the 40-year celebration of the Faculty, and what are some of the future prospects that we can anticipate in the Faculty?

The forty-year anniversary, also known as the ruby anniversary, is a very special one. Celebrating forty years in a marriage is often accompanied by traditional symbolism, and may be a year of passion, romance and devotion for the married couple. The flames symbolically burning in the ruby could also refer to the steadfastness and loyalty in the hearts of the couple. Just as the couple may celebrate their ruby anniversary, so, in the biblical sense, we may well be reminded of the forty years in the desert not an easy time for those involved. For the Israelites in the wilderness and for the married couple, the forty years may reflect a great deal of suffering, hardship, and pain. But at the same time, there were surely also success stories that might have been taken for granted and not always celebrated.

The Faculty has also had its stories of joy, success, achievement, overcoming challenges, looking beyond the horizon. Looking back to August 1980, when the first lecturers were appointed, there would have been overwhelming excitement and great anticipation on how the following year would look, when the first 47 students were due to commence their studies on 4 February 1981. From the history of the Faculty, these lecturers 
were significant figures from Pretoria and the now UKZN. Furthermore, the students played a vital role as well. Already at that stage, the Faculty welcomed female students even though the church had not yet opened the door to the ordination of women in the ministry.

Relationships between the Faculty and the DRC were very strong - to the extent that the Dean was also the chair of the Free State Synod and the General Synod. Added to this, the Dean was also the moderator of the Free State Synod, and lecturers also assumed church leadership positions. Over time, external factors, including the leadership of the University, influenced the Faculty to transform all the more.

After 1994, the Faculty opened its doors to black students of the DRCSA, and later students from denominations other than the DRC were welcomed. Lecturers from these other denominations became parttime lecturers in the Faculty, and recently full-time lecturers from other denominations have been appointed as staff members.

Over the years, the Faculty has at times struggled to meet its targets, especially in terms of first-time entry students; but because of innovations and external factors, student numbers have grown substantially and even beyond capacity. The Faculty is now looking at new ways to accommodate these students and prepare them for the labour market, also as servants of the Kingdom but without focusing only on ministry in the church. The Faculty has also grown more representative over the years in terms of inclusivity: there are today at least six black academic staff members, and we have a black Dean; all have been welcomed with open arms. Student demographics have changed altogether, and the great majority of students are now black. All are incorporated in a very spontaneous and welcoming manner to ensure that they feel that they have a home. The Faculty Council, known as Sola Gratia, fits in well with the SRC structures of the UFS and is now a well-recognised body.

The Faculty functions within a complex and multi-layered environment - globally, nationally, institutionally and internally. Within an environment of uncertainty and potential disruption, growing demands, profound changes, and growing discontent, the Faculty has to navigate a clear course. This requires nurturing of strengths, of pro-actively addressing challenges with wisdom, courage and creativity.

Institutionally at the UFS as a university, the Faculty functions in an encouraging and safe atmosphere of management appreciation. The imperatives of decolonisation, with its corresponding insistence on curricular transformation and equity of human resource appointment, continue unabated. For the past two years the Faculty with the rest of 
the University moved to a blended approach with the intention of moving toward full digitisation in years to come.

The number of academic staff with PhDs has grown to almost $100 \%$. Towards the close of 2019, the Faculty appointed new QPD lecturers, one with a PhD. So far, the Faculty has the highest percentage of lecturers with $\mathrm{PhD}$ qualifications at the UFS. With successful measures in place for mentoring our QDP lecturers to achieve their PhD qualifications, our Faculty will soon have reached the $100 \%$ level of lecturers with $\mathrm{PhDs}$.

We have plans in place to guide our young colleagues to receive their NRF ratings. One of the OT lecturers recently received his rating, and the Faculty now boasts 8 NRF-rated researchers. We are optimistic about the new applications that have been submitted.

With the newly established Faculty Advisory Board, the Faculty intends to engage and build stronger stakeholder relationships with different denominations, and also to ensure that students are linked directly with their denominations.

Our dream is to be among the leading faculties of theology and religion in South Africa, with top scholars recognised locally and globally, fully engaging with all denominations in relevant aspects of learning and teaching, research and the community. 